Chairman: LESLIE J. HARRIS, Sc.D., D.Sc., F.R.I.C., PRESIDENT of THE NUTRITION SOcIETY, Director of the Dunn Nutritional Laboratory, University of Cambridge and Medical Research Council.

\title{
Some Pre-Lind Writers on Scurvy
}

\section{By Anthony J. Lonenz, Sunkist Growers, Los Angeles 54, California, U.S.A.}

To-day a few tenuous sentimental attachments have become for me very real ties to the University of Edinburgh. One is long interest in the history of scurvy, whose conquest you are commemorating. The second tie goes back even further, almost half a century, to 1905 when our literature instructor insisted that no man could really lay claim to a knowledge of the English language unless he had read and re-read $A$ Window in Thrums. I took his admonition to heart and fell under the spell of Barrie for ever after, so much so, in fact, that I treasure highly my copy of that thin little volume The Entrancing Life, the address Sir James delivered on the occasion of his installation as Chancellor of the University of Edinburgh on 25 October, 1930. I know it almost by heart. The other attachments are somewhat more realistic. Two of the graduates of the medical school are friends (one of them is my family physician). One is in California, the other elected to remain in Great Britain. Both of them are professors of medicine in great medical schools, and both of them are pupils of Dr C. P. Stewart. That is why I so readily and proudly accepted Dr Stewart's generous offer to read this paper for me when I found myself unable to attend, although, like Barrie, in his opening remarks here 23 years ago, 'I am riven with misgivings. What have I dared!'

Any commemoration of Dr James Lind's $A$ Treatise of the Scurvy inevitably must focus attention upon those who helped to guide his thoughts.

It becomes a felicitous task for me, and one for which I am deeply grateful to The Nutrition Society who have permitted me to trot forth my hobby and remember a few of Lind's predecessors. By hanging out lanterns, feeble as the light of some of them may have been, they gave him direction. They do not detract from Lind's glory as a scientist. Living to-day and working with the tools of modern biochemistry Lind certainly would have occupied the high pedestal with Sir Frederick Gowland Hopkins.

Within our lifetime biochemistry has so changed perspectives that we may not appreciate fully the groping of our forefathers. Re-reading Lind's Treatise will reveal this clearly. He tried to lay aside 'all systems and theories of this malady which were found to be disavowed by nature and facts'. The amount of reading he did on the confused subject of scurvy was a formidable task in itself.

Before Lind the literature on scurvy was a welter of jumbled writings, many of them highly tinged with Sydenham's axiom that 'all disease could be described as natural history'. 'That is why Lind prudently segregated the medicinal from the 
folklore knowledge in his attempt to be objective. He reviewed more than 200 authors, abstracting sixty-one, some briefly and some in extenso. Yet Lind overlooked Moellenbrok's isolation of a potent crystalline antiscorbutic from a syrup of scurvy-grass, in 1676 , the penalty of the clinician's pardonable disregard for the weird 'scurvy recipts' of that day.

Of the sixty-one, only fourteen are English; twenty-one are German; twelve Dutch and five French. Denmark, Russia and Austria are represented by two each; and one reference each stems from the Hungarian, Swedish and Swiss literature on scurvy. In addition, Lind lists thirteen academic theses, all but four of them German, and sixteen academical disputations*. He appealed for help to obtain six 'academical disputations' or 'any other curious and useful observations made and published on the scurvy, or also such of the following academical performances as are distinguished by an asteric', (Koelesser, 1707; Crauford, 1707; Thiessen, I735; Alberti, I73 I; Burchard, I735; and Hilscher, 1747) adding 'I desire and earnestly entreat all men of study and learning who are possessed of them not to conceal them from me'.

There were no Nutrition Abstracts and Reviews in Lind's day, no bibliofilm or photostats, which make for such quick exchange of scientific information to-day. Perhaps that is why this antiquarian interlude is placed here-to slow down the programme a bit - slow down the zeal and pace of research reports which engender still more ardour for realism and relegate memories of humble and romantic beginnings to a scientific attic to gather dust and cobwebs.

Brief evaluation of some of these pre-Lind texts which I have collected may scarcely seem justified if only those authors reviewed by Lind were cited. We shall, therefore, discuss only a few of his authors and dust off a few others he ignored or overlooked. Among these are: Robert Boyle, Doctors William Clowes, John Woodall, John Colbatch, David Macbride, and a curious anonymous text of 1682 with its detailed recipe for making Mum and a jolly commentary on this drink. Each time I read it I am tempted to brew it.

The great medical library formed at the end of the fifteenth century by $\mathrm{Dr}$ Nicholaus Pol, Austrian-born court physician to Emperor Maximilian I, contains no books on scurvy. The reason for this is obvious. Pol's books dealt chiefly with Greek and Arabian medicine, with diseases of the Mediterranean regions where scurvy, as such, was virtually unknown.

The first actual bibliography of scurvy is that of Johannes Echthius (154I), the Dutch-born physician of Cologne, who referred to seven authors. Lipenius (1679), in his Biblioteca Realis Medica, only listed twenty-nine papers dealing with scurvy, and the great Mercklin's (I686) Cynosura Medica, only twenty-four.

'It has been no easy matter to obtain a knowledge of the many writings on this distemper', Lind (I753) remarks in the Appendix to the first edition of his Treatise, adding 'There have been collections made from time to time of the several authors

\footnotetext{
* Among the latter there occurs the first work on scurvy from an Italian University. This is the 1679 dissertation of Charles Patin, brother of the more famous Dr Guy Patin, Professor of Medicine at the University of Paris. Of Charles Patin, Lind, however, makes the laconic comment: 'Patin is more celebrated for his other writings than the Oratio de Scorbuto".
} 
on the plague, venereal disease, etc.: but no such have been compiled of writers on the scurvy'. For example, Felix Plater ( $165^{6}$ ), of Basle, in 1608 , believed that scurvy, like lues, had been brought from abroad by sailors.

This constant association of scurvy with venereal diseases, on the one hand, and with rheumatism, on the other, is evident also from Martin Lister's (I 694) introduction to the chapter on scurvy in his Sex Exercitationes Medicinales. Lister, the physician to Queen Anne, writes:*

'I have placed scurvy adjacent to the chapter on venereal disease, because of the newness of the disease, and because both are so closely related and have so many symptoms in common that they are not readily distinguished from each other, except by an experienced physician'.

With easy transition Lister follows his chapter on scurvy with one entitled de Arthritide, antiscorbutic remedies appearing throughout.

Johann Hartmann, whom Lind recognizes despite the Marburg physician's acceptance also of the symptomatic clinical similarity between lues and scurvy, 'commends for poor people in the scurvy the decoction of guaiacum wood with scurvy-grass'. This same Hartmann ( 1633 ), however, first reported the harmful effects of mercury in the treatment of scurvy, and the Hungarian army surgeon, Kramer (1737), claimed knowledge of 200 men 'destroyed by mercury given as an antiscorbutic'.

Another adherent of the lues-scurvy tenet and perhaps the most widely read authority on scurvy before Lind, was Severinus Eugalenus, a Friesian physician, whom Lind accussed of 'extreme ignorance in physic'. Eugalenus, who in 1604, practised medicine in the cities of Emden and Amsterdam, quoted 200 such cases in his De Morbo Scorbuto liber (Eugalenus, I623). He expressed surprise over the rapidity with which the venereal contagion spread, and gave as the only distinguishing diagnostic sign between lues and scurvy the pulsus inordinatus, the quick, small, uneven pulse of scurvy and the appearance of the urine.

Eugalenus was everywhere credited with speedy miraculous cures of scurvy, although Lind said: 'Eugalenus had not talents sufficient to form any sort of theory'. Lind's review of Eugalenus is one of the lengthiest in his book, extending over eighteen pages.

Lind makes the Dutch physician, Balduin Ronsseus, facile princeps. Ronsseus suggests that cold damp air of the sea and the seashore is the principal cause of scurvy. His is the first book written expressly on scurvy and was published in 1564. A later edition of Ronsseus ( $15^{85}$ ) combined the epistolae of Echthius and Langius as well as the observatio of Wierus as a sort of compendium of the current views on scurvy. Ronsseus also held to the theory of involvement of the spleen in scurvy. Both Ronsseus and Echthius, writing separately, interpreted Pliny's ( 70 ) description of the disease, which afflicted the Roman army under Germanicus, as scurvy.

\footnotetext{
* 'Proximo autem Lui Venereæ loco Scorbutum posui, \& propter morbi novitatem, \& quod illi tot tantisque signis communibus, valde affinis sit; imo unum ab altero dignoscere, nisi admodum exercitato medico, haud ita facile est'.
} 
Wier (Wierus) (1567), copying Echthius, and Bruner (Brunerus) ( ${ }_{5} 89$ ), copying Wierus (adding only that leg pains preceded the actual onset of scurvy) well might have justified the subhead in Lind's preface Dies Diem Docet, and the words:

'To know a disease and to cure it being the utmost essential things to be learned, I have, therefore, transcribed the symptoms and the cure of the scurvy from those authors where they do not entirely copy from each other. I hope such motives (truth, and good of mankind) will to the candid and to the most judicious be a sufficient apology for the liberties I have assumed'.

In re-reading the principal pre-Lind authors seriatim one observes the transitions from land to sea scurvy, or purpura nautica. One also sees the transition of the concept of scurvy as a winter epidemic among urban populations and its entity as'a deficiency disease when studied in the isolation of the sailing ship when voyages of discovery increased in duration sufficient to permit complete deprivation of antiscorbutic stores.

It was Dr Thomas Willis (I684) and his copier, Dr Walter Charleton (I672), physician to King Charles II, who seem to have 'exceeded all others in multiplying divisions and classes of scurvys', as Lind remarks, adding that Aegidius Hoffmann's so-called 'Muriatick Scurvy' seemed to be merely 'a chimerical distinction' attributed to the drinking of sea water, then fashionable as a physic.

The general implication of salt in sea scurvy is too well known to merit discussion.

Though land scurvy was, in its epidemic era, regarded as the winter disease of the cities, localized sometimes as in 'The Disease of London' or the 'Dutch Distemper' (in Scotland it was descriptively called 'blacklegs' from its ecchymoses of the extremities), it was for the most part the disease of the poor. Its remedies were the lowlier herbs, the cresses, the scurvy-grasses, so fittingly named, although only one, Cochlearia officinalis, or spoongrass, rightfully bore this name. So deep was the folk-faith in scurvy-grass that Moellenbrok (Mollimbrochius) (1676), in his Cochlearia Curiosa* said:

'It hath been declared above, that Scurvygrass doth not grow in all places, and chiefly not in the Eastern parts of the world, in which it is never found, nor will its seed sown in the Earth there produce it, for it will only grow in the Western parts, in which the Disease which it cureth, viz., the Scurvy is frequent'.

Hildanus Fabricius $\dagger$ ( 1629 ) in his de Conservanda Valetudine, however, questioned the claim by pointing out that 'Nature is backward in producing scurvy-grass in Switzerland, because through God's mercy this Country has hitherto been free from this grievous plague The Scurvy'.

Fabricius, according to Shipley (1929), states that scurvy appeared for the

* 'Englished from the German by Thomas Sherley, M.D., and Physitian in Ordinary to His present Majesty'.

† In 1627 Fabricius (Hildanus), who has become one of the controversial figures in scurvy lore, attempted twice to grow Dutch scurvy-grass in his garden in Switzerland, having 'carefully sowed the seed which he procured out of Holland'. Failing in his first, he succeeded in his second attempt, adding his prayer 'that it might not prove an unlucky Omen to the Swissers, and a Forerunner of this Disease, of which it is a Remedy'. 
first time in North Germany in 1486 . He is also the recipient of the letter dated I5 October, I622, from a Dr Ludovic Schmid, physician to the family of George Frederick, margrave of Baden. Dr Schmid (see Schmid, 1627) describes what he calls a case of scurvy in the I4-month-old son of the margrave. Lind, however, dismisses the Schmid letter-evidence with 'not deserving of notice', although he refers to 'Hildanus' as a 'celebrated practitioner'.

Thomas Sydenham (1685) who, Lind says, did 'not quite believe in scurvy' but whom he acknowledged as 'The English Hippocrates', employed 'leaves of fresh scurvy-grass' for his antiscorbutic electuaries and recipes. In two remedies Sydenham combined scurvy-grass with oranges. In one he used the juice of half an orange in a pint of the scurvy-grass beer; and in the other, the pulp of a whole orange combined with both the leaves and the seeds of scurvy-grass steeped in half a pint of white wine.

Sydenham's contributions to medicine are too well known to warrant extensive comment here except for his relationship to Robert Boyle, and the latter's array of fantastic remedies against scurvy and its manifestations. A study of the great chemist's remedies, or receipts, as he calls them, can only lead to the conclusion that Boyle, like so many of us to-day, apparently failed to take his physician friend's advice seriously and elected to experiment by compounding his own remedies.

Boyle's (1696) Medicinal Experiments : or, a Collection of Choice and Safe Remedies, etc. contains eighteen recipes for antiscorbutic remedies; four of them for the disease itself, and thirteen 'to fasten the loose teeth', the result of scurvy. Still another, a true antiscorbutic decoction, while making no mention of scurvy, is prophetically entitled 'To Promote the Healing of Wounds'. Boyle confesses to having suffered from the 'scorbutic colic'*, for which he gave the following recipe:

'Take English Barley, and having well wash'd it, boil it in a sufficient quantity of fresh Spring-water till it be just ready to burst: Then pour off the clear upon the yellow part of the Rhinds of Lemons, freshly cut off from the white part, and put them into a Bottle, which being carefully stopt, the Liquor is to be kept so for Use, which is, that the Patient make it his constant Drink'.

The remedies which Boyle concocted and advised, (some of them he admits were

* Boyle blames his delicate constitution on being 'the thirteenth or fourteenth Child of a Mother, that was not above 42 or 43 Years old when she dyed of a Consumption, 'tis no wonder I have not inherited a robust, or healthy Constitution'.

'For this Mischance happening in Ireland, and I being forc' $d$ to take a long journey, before I was well recovered, the bad Weather I met with, and the as bad Accomodation in Irish Inns, and the mistake of an unskilful or drunken Guide, who made me wander almost all Night upon some Wild Mountains, put me into a Fever and a Dropsie.'

'But this after the foregoing Relation may well be said, that it need be no great wonder, if after such a train of Mischiefs, which was succeeded by a Scorbutick Cholick that struck into my Limbs, and deprived me of the use of my Hands and Feet for many months, I have not enjoy'd much Health, notwithstanding my being acquainted with several Choice Medicines; especially since divers of these I dare not use, because by long sitting, when I had the Palsie, I got the Stone, voiding some large ones (as well as making bloody Water) and by that Disease so great a tenderness in my Kidneys, that I can bear no Diureticks, tho' of the milder sort, and that I am forced to forbear several Remedies for my other Distempers, that I know to be good ones, and amongst them divers, that by God's Blessing, I have successfully try'd on others'. 
merely copied from other writers) show a predilection for "Terra Japonica in Claret Wine', sometimes with and sometimes without 'allom'. Throughout, it can be seen that Boyle's concern was chiefly with the gingival involvement, the 'laxity of the gums' as he paraphrases 'scorbutic gume' in his Recipe Number Ten of Book Three.

In returning to Martin Lister (I694), Sydenham's contemporary, one finds espousal of the cold and salt theories of scurvy as propounded by Eugalenus. His twelve case reports* of scurvy (Aegrotus I to XII) provide interesting reading for the clinician to-day and reveal Lister's various treatments of the disease. Medication in the last three cases proved so effective that Lister concluded that 'the greater "ungrateful" degree of acidity of immature fruits' alone does not seem to be the full measure of their antiscorbutic value but that in the citrus fruits, lemons coming first, followed by oranges and citrons, 'reside a special exotic principle curative of scurvy superior to bezoar stones and the like', concluding with, 'without boasting, however, I have observed in all my medical practise that with no other remedies were such successful results effected as with lemons'.

Lister, however, was not the first English physician to employ citrus fruits in the treatment of scurvy. That distinction, as Shipley (1929) claims, should go to John Woodall. Nor am I the first to be bothered by the failure of Lind to include Woodall's (1639) The Chirurgeon's Mate, or Military and Domesticke Surgery among his references. This thin folio volume published in 1639 , with a dedication to King Charles, seems to have escaped the notice of almost all medical writers of the eighteenth century. Dr David Macbride, a Dublin contemporary and admirer of Lind, writes in 1764 :

'The only places where I see it mentioned are in Wiseman's preface, and in the preface to Turner's surgery; but it is not to be found in Haller's catalogue, neither in Heiszer's Bibliotheca Chirurgica; nor, which is still more to be wondered at, in Lind's Bibliotheca Scorbutica; notwithstanding that Woodall hath left a very

* CASE

No. I. A robust soldier, returning from camp with a diarrhoea and oliguria, his whole body covered with red spots, recovered after medication with an anise, fennel and ginger infusion in white wine.

No. 2. Received nasturtium and scurvy grass juice in red wine.

Nos. 3. One obese and the other emaciated, both covered with red petechiae and showing signs 4. of hematuria, died 'wasting away'.

No. 5. The 50-year-old Prebendary Cooke of York Cathedral, whom Lister diagnosed as scorbutic, died 'despite application of an emollient poultice of scurvygrass'.

No. 6. A 'very obese' man named Batavus was diagnosed as scorbutic by the gum and tongue signs, died following violent nocturnal epistaxis.

No. 7. A youth, also suffering violent nose bleeds, together with purplish-black maculae, terminated fatally. No note is made of medication.

No. 8. A 5-year-old boy, died of haemorrhage, to which Lister adds: 'N.B. Blood flowed from the maculae themselves'. He failed to recall what medication had been employed.

No. 9. A ro-year-old son of a merchant named Waller died after a typical gingival involvement, that finally affected the tongue and throat as an ulceration which prohibited the administration of either medicine or food.

Nos. 10. A 6-year-old boy and an 8-year-old girl as well as another girl, recovered upon treatment

II. with his later prescriptions of ('succi limonum, succi cochleariae, aurantiorumve succi')-

12. 'the juice of lemons, scurvygrass or orange'. 
excellent discourse on the scurvy, his description of which appears to have been drawn from his own observation, and his method of cure founded on experience, for he served both at sea and in the army' (Macbride, I764).

Woodall (1639) laments that none of his 'countremen had, out of their experience, taken in hand sincerely to set down to posteritie the true causes, signes, and cure thereof; neither left any caveats, instructions, or experiences, for the prevention or cure of the same'. Modestly Woodall acknowledges the causes to be 'so infinite and unsearchable, as they far exceed my capacity to find them out'.

Woodall's autopsy reports may well interest the pathologist, and his dietetic advice for treatment of patients with scurvy is quite specific:

'An oatmeal caudle, with a little beer or wine, the yoke of an egge, and some sugar; or a broth, made with currants or other fruits, with spices and sugar; and, for drink, barley water, with some juice of lemons, if it may be had, if not, with oyl of vitriol and sugar. The juice of lemons is a precious medicine, and well tried, being sound and good: let it have the chief place, for it will well deserve it. It is to be taken twice a-day, a spoonful or two with sugar'.

Woodall's protagonist, Macbride ( 1767 ), wrote an entire book filled with illustrations of apparatus in which he performed his 'fixed air' experiments on the digestion of mutton, in an attempt to keep it sweet, or if already putrid, to sweeten it. The Dublin surgeon's dabbling was designed to prove the superiority of his malt or wort over Lind's citrus cure for introduction into the Royal Navy. Confidently, however, without having treated a single case of scurvy he sent out a quantity of his malt for clinical tests. Macbride based his ideas, second-hand, on 'the theory, which makes the cure of the sea scurvy to depend chiefly, if not altogether on the fermentative quality of the fresh vegetables', to which he says 'the ingenious $\mathrm{Dr}$ Lind ascribes somewhat', adding 'yet his theory rests chiefly on the saponaceous, attenuating and resolving virtue, which, according to him "is the chief and most essentially requisite quality in the antiscorbutic mixture". (Lind, p. 304)'.

If Macbride's 'fermentative' might be misinterpreted in the sense of biochemical nomenclature for enzymic, the Dublin surgeon might be regarded as a prophetic genius instead of the proponent of an untried theory that scurvy is a 'putrefactive diathesis brought on by excessive moisture' amenable to the wearing of dry clothing and a draught of his wort. On the other hand, Macbride may seem to have had a rather modern and fundamental concept of scurvy, in that he believed its putrefaction resulted from the loss of a 'principle, forming the cement, or bond of union', upon which the 'firmness, soundness, and perfect cohesion of bodies, chiefly depend'. He therefore conducted elaborate in vitro experiments to trace 'the progress of digestion, and showing that the principle above hinted at is received into animal bodies by way of the chyliferous canals'. Perhaps we are tempted to read too much into Macbride's verbiage without a sufficiently critical examination of his actual experiments. Words, however, tempt the reader as well as the writer.

With Macbride's untried wort and Sydenham's (1685) antiscorbutic 'twelve bottles of small beer, acidulated with Spirit of Vitriol, every twenty-four hours', 


\section{A PROFITABLE AND NECESSARIE}

Booke of Obferuations, for all thofe that are burned with the flame of Gun powder, \&c. and alfo for curing of wounds made with Musket and Caliuer hoot, and other weapons of war commonly vfed at this day both by fea and land,as heerafter thall be declared :

VVith an addition of molt approoued remedies, gathered for the good and coinfort of many, out of diuers learned men both old and new Writers :

Laft of all is adioined a fhort Treatife, for the cure of L.wes Venersa,by vinctions and other approoued waies of curing, heertofore by me colleeted : and now againe newly correated and augmented in the yeere of our Lorde

1596.

By WILLIAM CLOWES one of hir Maiefties Chorurguons.

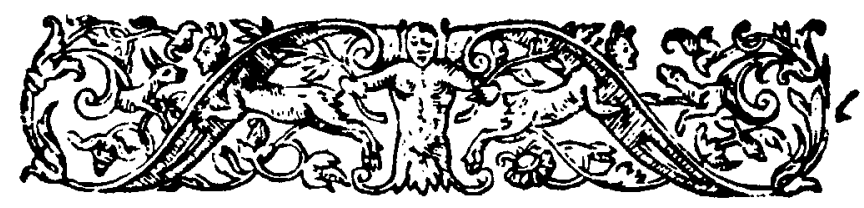

Imprinted at London by Edm.Bollifant, for Thomas Dawfon.

1596

Fig. I. Facsimile of title page of Clowes's (1596) book 


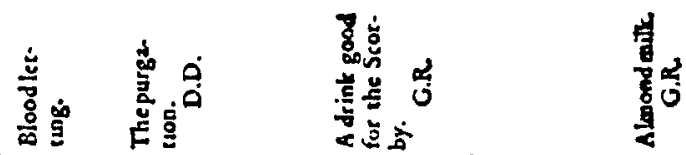
+

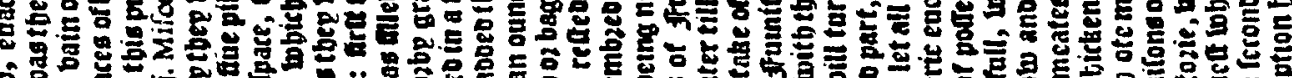

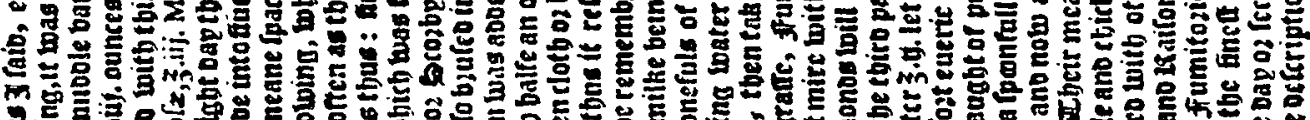

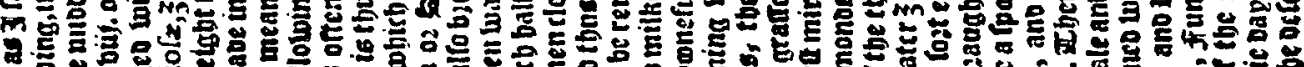

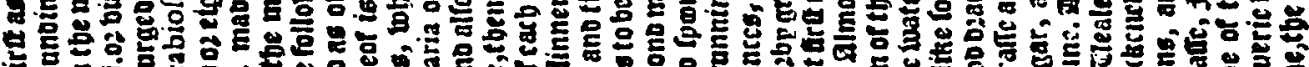

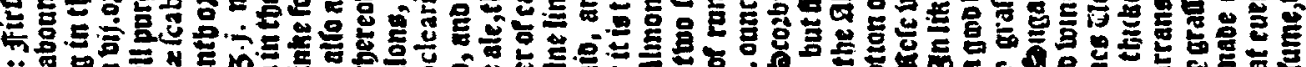

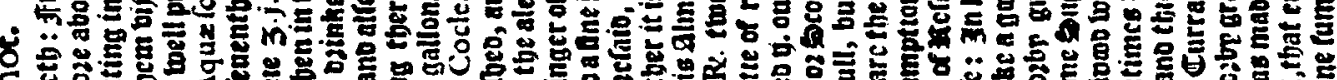
c

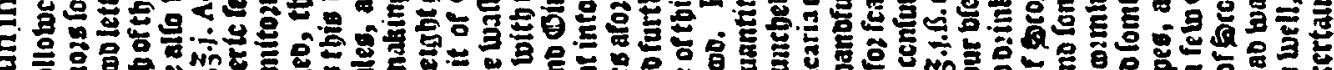

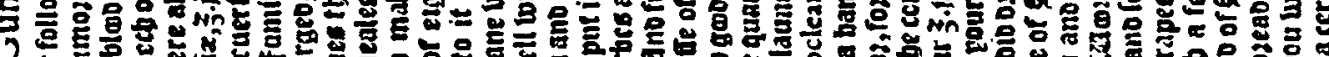

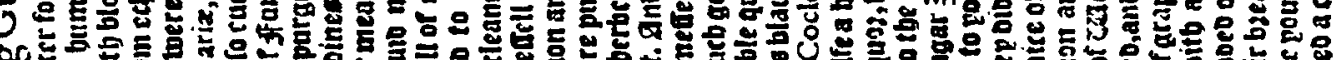

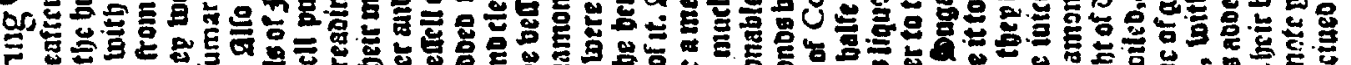

-

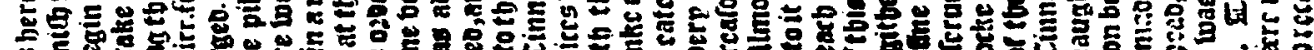

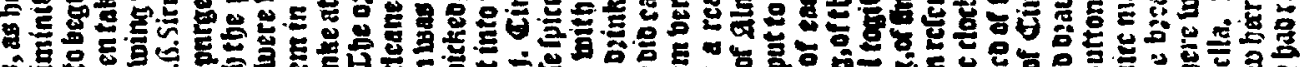

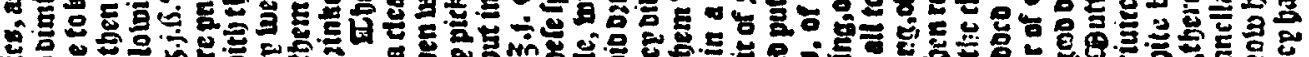

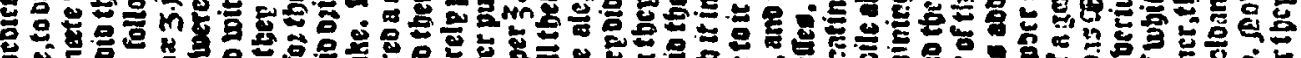

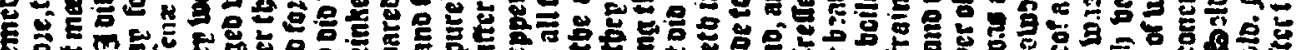

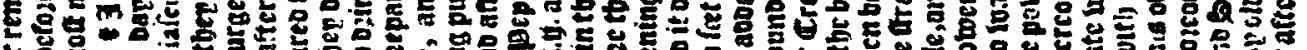
芯品

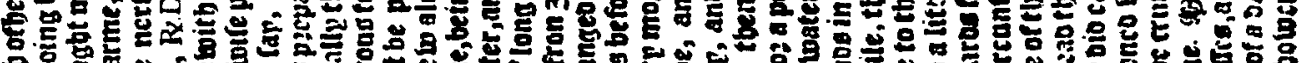

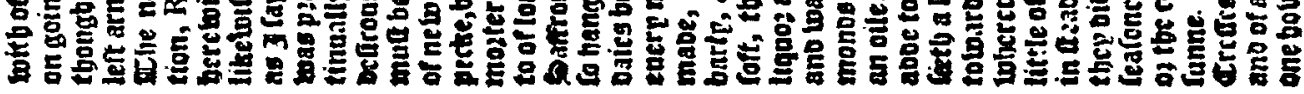

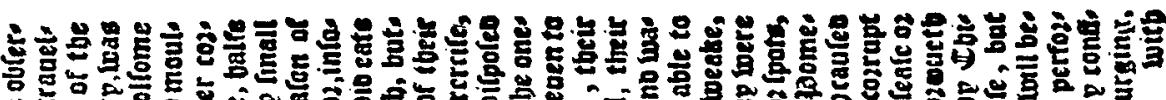

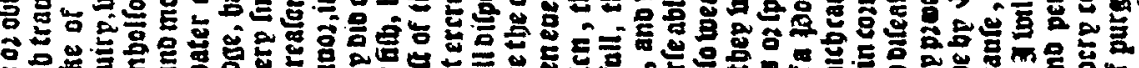

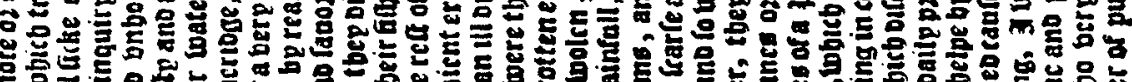

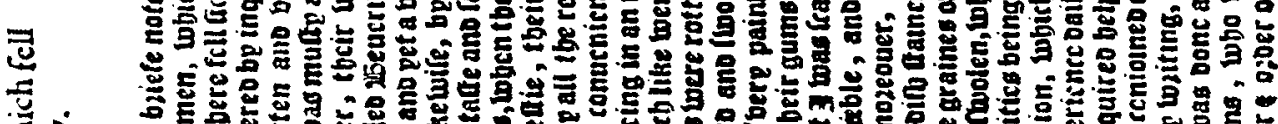

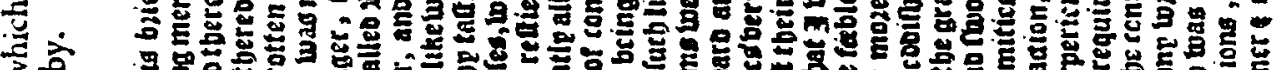

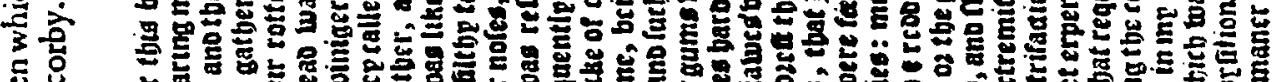

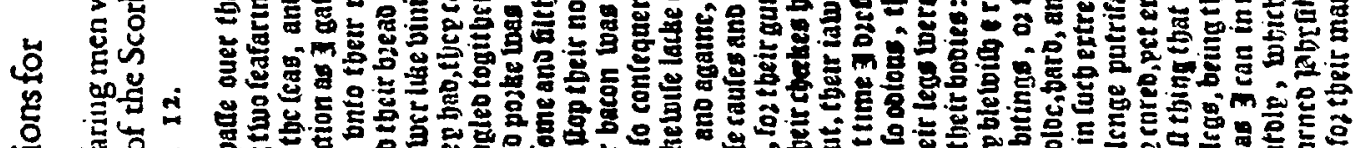

.

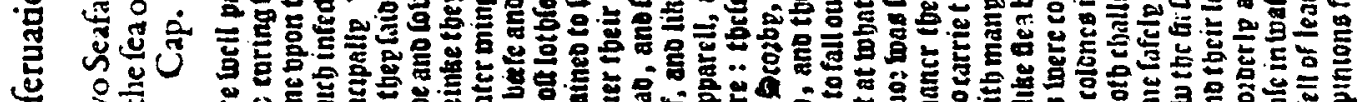

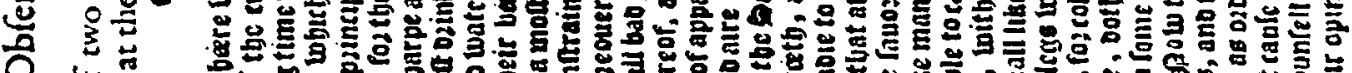

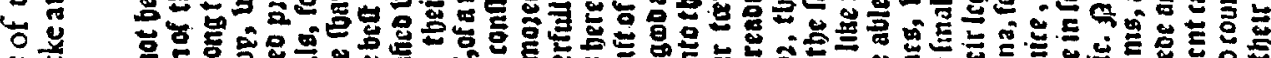

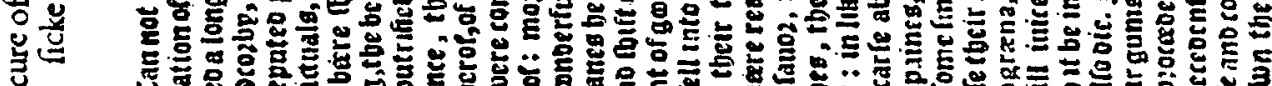
$\stackrel{\text { g }}{=}$

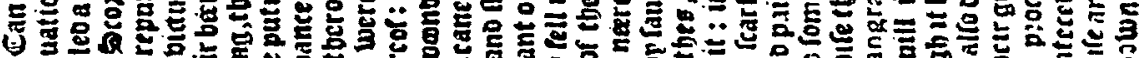

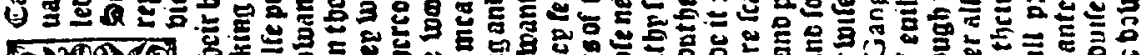

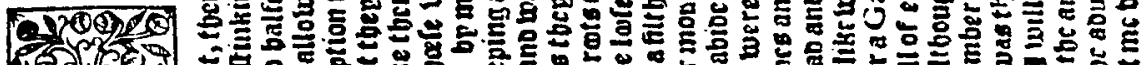
190he 




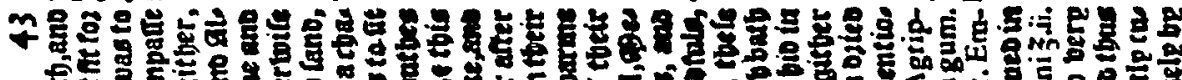

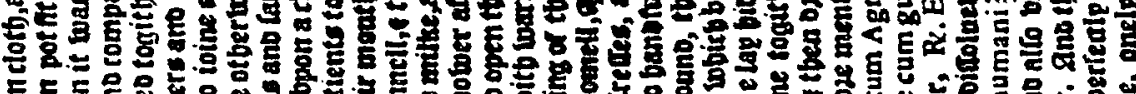

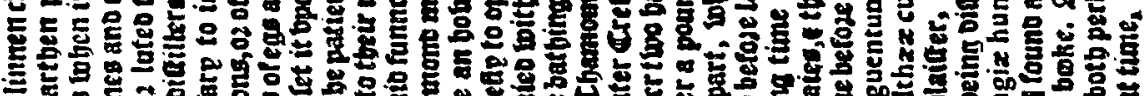

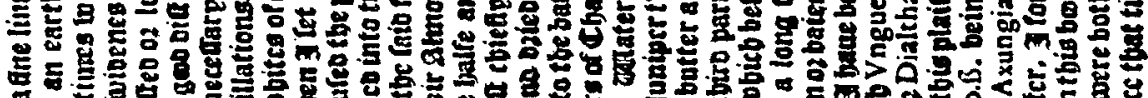

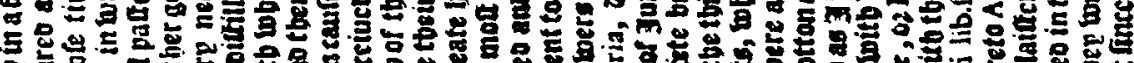

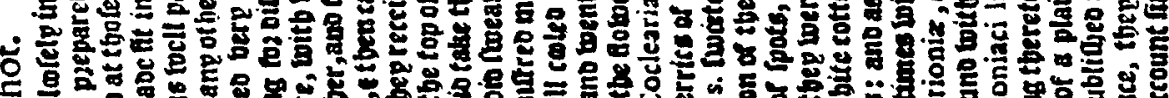

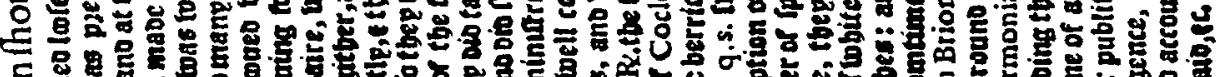
등

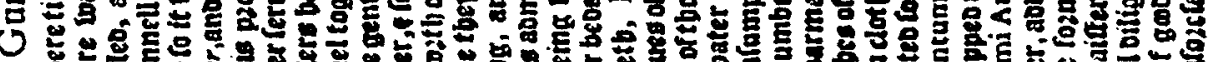
م0

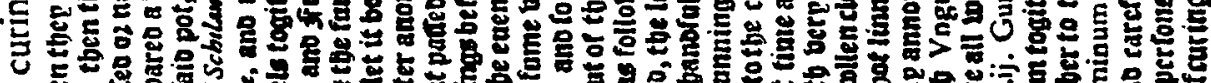

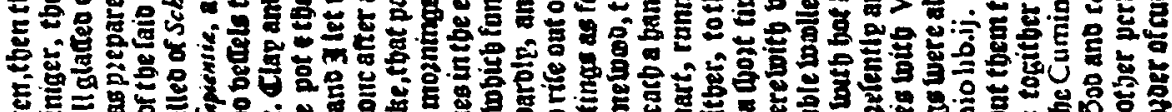

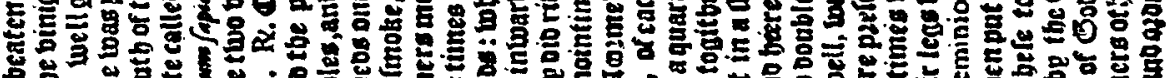

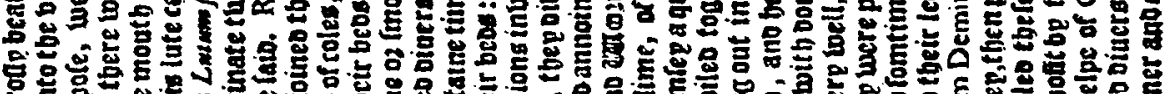



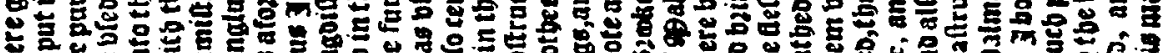

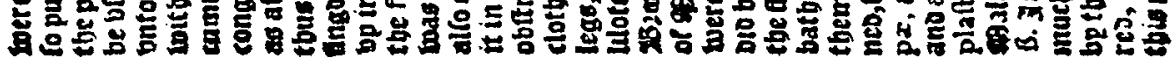

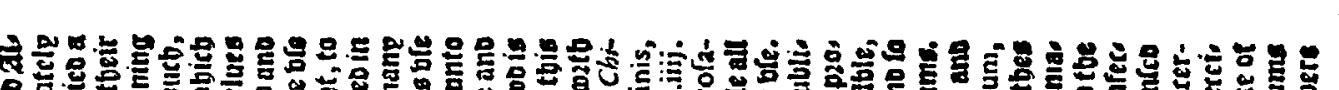

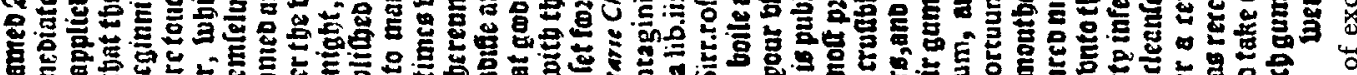

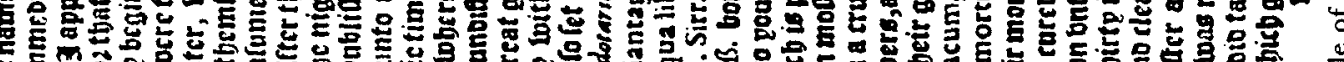

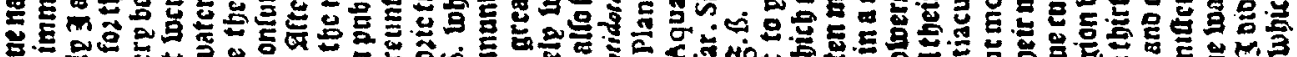

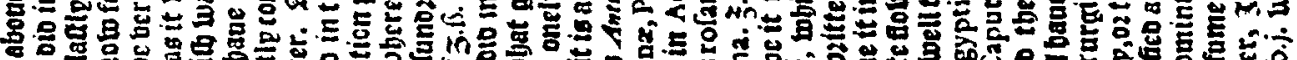

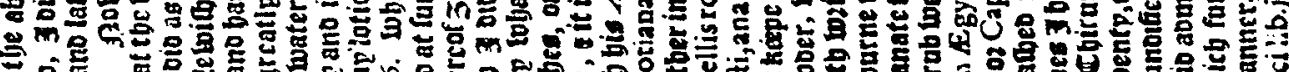

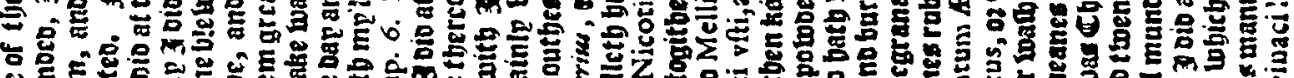

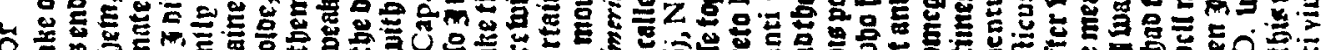



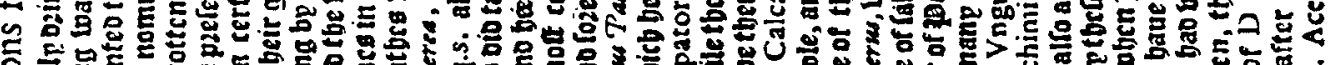

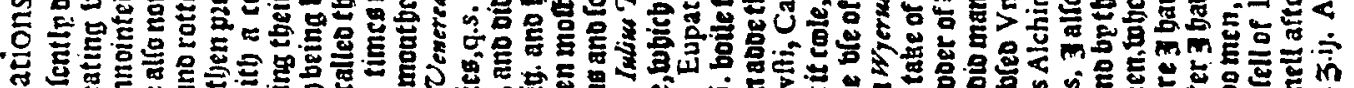

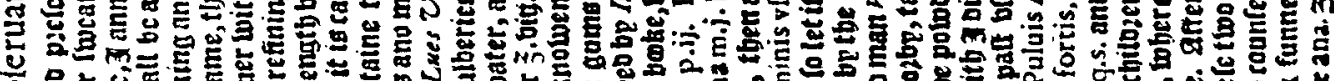

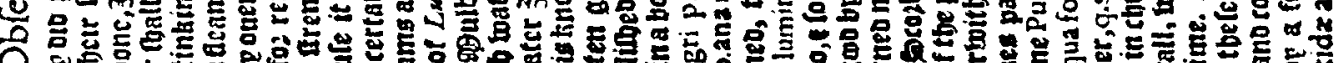

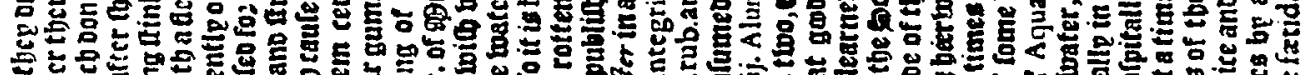

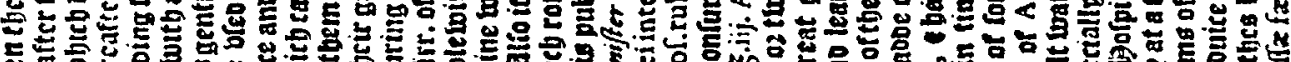
5

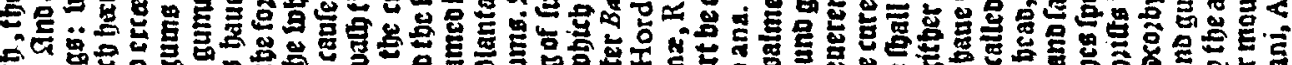

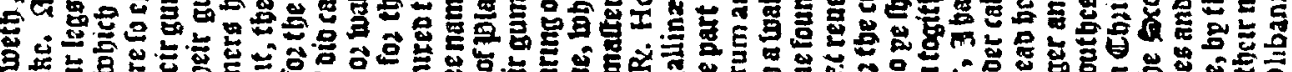

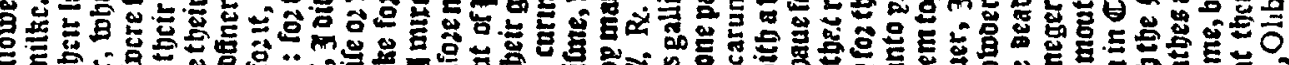

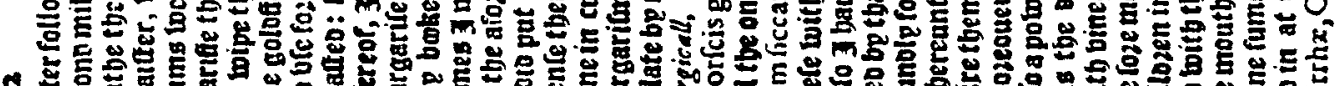



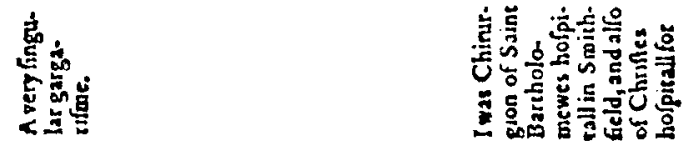


it is small wonder that Edinburgh's own Dr John Comrie (1932) remarked that: 'The I7th Century sailor must have been a sturdy fellow!'.

Almost a century before Macbride, and not unlike him in many respects, the cantankerous, Dr John Colbatch (I700) published his Collection of Tracts, Chirugical and Medical. The first of these $A$ New Light of Chirurgery dealt with Colbatch's 'discovery of a more safe and speedy way of curing wounds than heretofore usually practised, with several experiments'.

Having served in the war in Flanders as a military surgeon, where he was in charge of a field hospital at the siege of Namur, Colbatch records case report after case report in which he cured most seriously wounded soldiers. His remedies were two-fold, one of them his secret vulnerary powder, with which he not only dressed the wounds but which was injected with a syringe, and the other internal, namely 'treatment with a nutritious diet'. The possibility of scurvy* supervening seemed ever in his mind. Colbatch claimed to have made upwards of one hundred 'experiments upon Dogs and other animals, wounding them in the most desperate manner I could contrive'. Colbatch was knighted on 5 June 1716 some 12 years before his death.

Colbatch's boasting about miraculous cures, and his secret vulnerary powder, irked his medical colleagues no end, yet he was frank in prescribing citrus fruits as the acids $\dagger$ of choice for almost every distemper, from the healing of wounds to smallpox and viper stings $\ddagger$, as well as in scurvy and what he regarded as its concomitants, gout, arthritis and rheumatism\$.

Selfishly, Colbatch retains a warm spot in my heart, not merely for his enthusiastic approval of citrus fruits, but for his elegant and eloquent recipe** for 'lemmonade, the most grateful liquor in the World'. My Bavarian vintner forebears

*'I now com to treat of the disuse of Alkalies in the Scurvy, that reigning Distemper, from which few are altogether free; and is by most accounted incurable, or at least for the most part proves so. But here $I$ expect the cry of all Mankind against me; what! say there is no Acidity in the Blood in the Scurvy? What but an Acidity in the Blood causes the breaking out of Scabs, Pimples, Blotches, etc. on the Skin?'

†'Why should we fly to Acids chymically prepared, when, as I said before, Nature has provided Oranges, Lemons, Citrons, Limes, and a great many more not necessary to mention, which for the most part answer our intentions, if skilfully given by an experienced hand?'

'But however, nothing is more grateful or delightful to an Hydropical Person, than a slice of Lemon or some such thing. Common Salt I allow will excite Thirst, but not quatenus Acid, for Spirit of Salt will take it off as soon as anything. Again, if acids were so pernicious to Mankind, as some would make us believe, I wonder the College of Physicians don't unanimously petition the Parliment to prohibit the Importation of Orange and Lemons in such vast quantities as we now have 'em' (Remarks upon Dr Tuthill's vindication of his Objections against my Hypothesis, p. $55 \mathrm{I}$ ).

I As for what I have mention'd concerning the Efficacy of Juice of Lemons, in immediately abating and taking off the violent Symtoms that attended a Person who had bin bit with a Viper, after the Volatil Salt of Vipers, and other Antidotes had in vain bin given; I find the very same thing taken notice of by Hoffman in his Clavis Pharmaceutica Schroderiana, pag. 444, 445'.

$\S$ 'If they are at any time very thirsty, they may drink Lemmonade; and if what they eat dos not digest well, they may about an hour after dinner eat the Pulp of a Lemon cut into slices, with som double-refined Sugar, it greatly helping Digestion, and strengthening the Stomach'.

'The moderate use of all acid Fruits is very convenient, but such as are very luscious and sweet are to be avoided'

** "Take of clear Spring-Water one quart; then pare off the outward thin Rine of two Lemmons, and put into it; afterwards squeeze in the Juice of the Lemmons, and then sweeten it with about two Ounces of fine Sugar'. 


\section{The W A of Making}
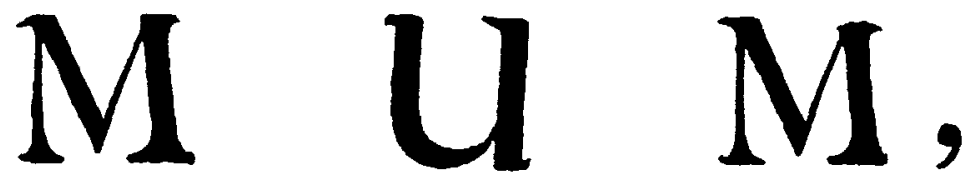

WITH SOME



UPON THAT
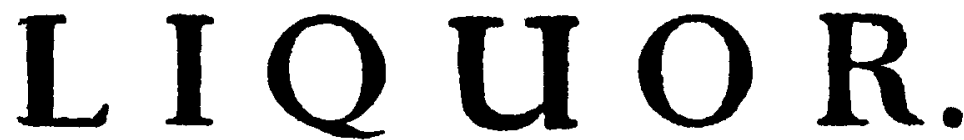

T $N$ the firft place, I will give fome inftructions how to make Mum, as it is Recorded in the Houfe of Brunswick, and was fent from thence to General Monk.

To make a Veffel of 63 Gallons, the Water mutt be firft boyl'd to the Confumption of a third part, let it then beBrew'd according to Art with 7 Bufhels of Wheat-Malt, one Bufhel of Oat.Malt, and one Buthel of Ground Beans, and when it is Tun'd, let not the Hogihead be too much fill'd at firf ; when it begins to work, put to it of the inne: Rind of the Firr three pounds, of the tops of Firr, and Birch, of each one pound, of Carduus BenediEtur dried, three handfuls, Flowers of Rofa Solis, two handfuls,

Fig. 2. Way of making Mum (Anonymous, 1682). 


\section{Remaks upon MUM.}

handfuls, of Burnet, Betony, Marjoram, Avens, Pennyroyal, Flowers of Elder, Wild Thyme, of each one handful and a half, Seeds of Cardamum bruifed, three ounces, Bayberries bruifed, one ounce, put the Seeds into the Veffel; when the Liquor hath wrought a while with the Herbs, and after they are added, let the Liquor work over the Veffel as little as may be, fill it up at laft, and when it is ftopped, put into the Hoghead ten new laid Eggs, the Shells not cracked, or broken : ftop all clofe, and drink it at two years old, if carried by Water it is better. Dr. Eg idius Hoffman added Water Crefles, Brooklime, and Wild Parfley, of each fix handfuls, with fix handfuls of Horfe Rhadifhrafpod in every Hogih ead: it was obferv'd that the Horfe Rhadifs made the Mum drink more quick than that which had none.

By the compofition of Mum we may guefs at the qualities, and properties of it, you find great quantities of the Rind, and tops of Firr in it; therefore if the $\mathrm{Mum}$ makers at London are fo careful, and honeft, as to prepare this Liquor after the Brunfwick fafhion, which is the genuine and original way; it cannot but be very powerful againft the breeding of Stones, and againft all Scorbutick Diftempers. When the Suedes carried on a Mollenbroc. ac War againft the Mufcovites, the Scurvy did fo domineer Arthritite vag. amongft them, that their Army did languifh, and moul. Scorbut.p.116. der away to nothing, till once encamping near a great number of Firr Trees, they began to boyl the tops of them in their Drink, which recover'd the Army even to. a miracle; from whence the Suedes call the Firr the Scorbutick Tree at this very day.

Fig. 2 cont. Way of making Mum (Anonymous, 1682). 
As for Eggs in the Compolition of Mum they may contribute much to prevent its growing fower, their thells fweetning Vinegar, and deftroying Acids, for which reafon they may be proper in reftoring fome decay'd Liquors, if put whole into the Veffel. Dr. Stubbs oldenburg's in fome curious Obfervations made in his Voyage to $\mathrm{fa}$ maica, affures us, that Eggs put whole into the Veffel Pbilof. Tranf. will preferve many Drinks even to admiration in long Voyages: the Shells, and Whites will be devour'd and loft, but the Yolks left untouched.

Dr. Willis prefcribes Mum in feveral Chronical Di- Dr. willis de ftempers, as Scurvies, Dropfies, and fome fort of Con- Scorbuto. Phare fumptions. The Germans, efpecially the Inhabitants of macent. RatioSaxony, have fo great a Veneration for this Liquor, that they fancy their Bodies can never decay, or pine away, as long as they are Lin'd, and Embalin'd with fo powerful a preferver; and indeed, if we confider the frame, and complexions, of the Germans in gencral, they may appear to be living Mummies. Bur to conclude all in a few words, if this Drink call'd Mum, be exactly made according to the foregoing inftructions, it muft needs be a moft excellent alterative Medicine, the ingredients of it being very rare and choice fimples, there being fearce any one Difeafe in Nature, againft which fome of them are not prevalent, as Betony, Marjoram, Thyme. In Difeafes of the Head; Birch, Burnet, Water-Creffes, Brooklime, HorSe-Rbadifh in the moft inveterate Scurvies, Gravels, Coughs, Confumptions, and all obftruetions.

Fig. 2 cont. Way of making Mum (Anonymous, 1682).

and my California oenologist friends, I feel certain, also subscribe to Colbatch's happy afterthought 'but if it be too cold for anyone's stomach, it may be made a little warmer with half a pint of Old Hock'!

Somewhat more alarming, however, were some of the ideas of Boerhaave (I 728 , 1742,1783 ), the Dutch authority on scurvy, and another contemporary of Lind. The French edition of Lind's Treatise, published in Paris in 1783 , has Boerhaave's Treatise appended as part 3 , in commentary form by Van Swieten. 'Scurvy is particularly violent in those who do not exercise', writes Boerhaave and 'a lazy and sedentary life must therefore dispose one toward this malady', leading to a thickening of the blood or 'crassamentum'.

The 'crassamentum' seems to have been a sort of forerunner of 'sludged' blood 
and increased sedimentation rates. How easy it becomes to reinterpret the foggy language of old writers and make them out geniuses, after all!

Misunderstood and forgotten great men are deserving of more than sentimental sympathy. California's Huntington Library has such an excellent copy of the elder Dr William Clowes' (I596) Profitable and Necessarie Booke of Observations, with its The cure of two Seafaring men which fell sicke at the sea of the Scorby (see Fig. I*). Why Lind failed to include this in his bibliography will always remain a mystery to me, since the widely read Clowes fulfilled all of Lind's requirements of first-hand clinical observation. Clowes, who was Queen Elizabeth's physician, and 'one of hir maiesties chirurgions', was one of the first to abandon Latin and dare to write his medical observations in the vernacular. His remedy was an 8gallon batch of new ale into which a "peck of "coclearia or scorby grasse" purely picked, and cleane washed, and also brused in a stone morter' was hanged along with cinnamon and ginger. To paraphrase any of it, or to put it into modern English, would destroy its clear, narrative flavour.

Clowe's recipe for making the antiscorbutic ale popularly known as Mum is not as precise as the one I found many years ago in The Natural History of Coffee, Thee, Chocolate, Tobacco, Etc., and also the way of making MUM, with Some Remarks upon that LIQUOR.

The recipe for Mum (Anonymous, I682) is that of the House of Brunswick, from whom a General Monk seems to have obtained it. Chemists may be interested in the novel yet quite scientific way in which 'ten new laid eggs, the shells not cracked' were used to buffer the drink as it gradually acidified (see Fig. 2).

It was this recipe that set me on the trail of Dr Andreas Valentinus Moellenbrok (Molimbrochius) who clearly described what might well have been the isolation of ascorbic-acid crystals (Moellenbrok, I676). The Leipzig physician-pharmacistchemist, in his I95-page book on scurvy-grass entitled Cochlearia Curiosa experimented on ways to obtain various concentrates and finally to isolate the 'volatile spirit' of scurvy-grass. He indicates clearly that he was aware of the lability of the antiscorbutic principle to atmospheric oxidation. Even in Sherley's English translation this seems apparent (see Fig. 3).

The true scurvy-grass of history is the Cochlearia officinalis, Linn., 'spoonwort', belonging to the lepidums or pepperworts of the larger family of cruciferae, or cresses. All of them are marked by pungency and antiscorbutic properties of their fresh leaves now well established also by chemical determination of their ascorbicacid content. The apothecary of Lind's day had for his guide in compounding of cochlearia prescriptions, a Latin verse by Johannes Joachim Bechorus on $\mathrm{p}$.

* Our facsimile is made available through the kindness of Mr Leslie E. Bliss, Librarian of the Huntington Library. 


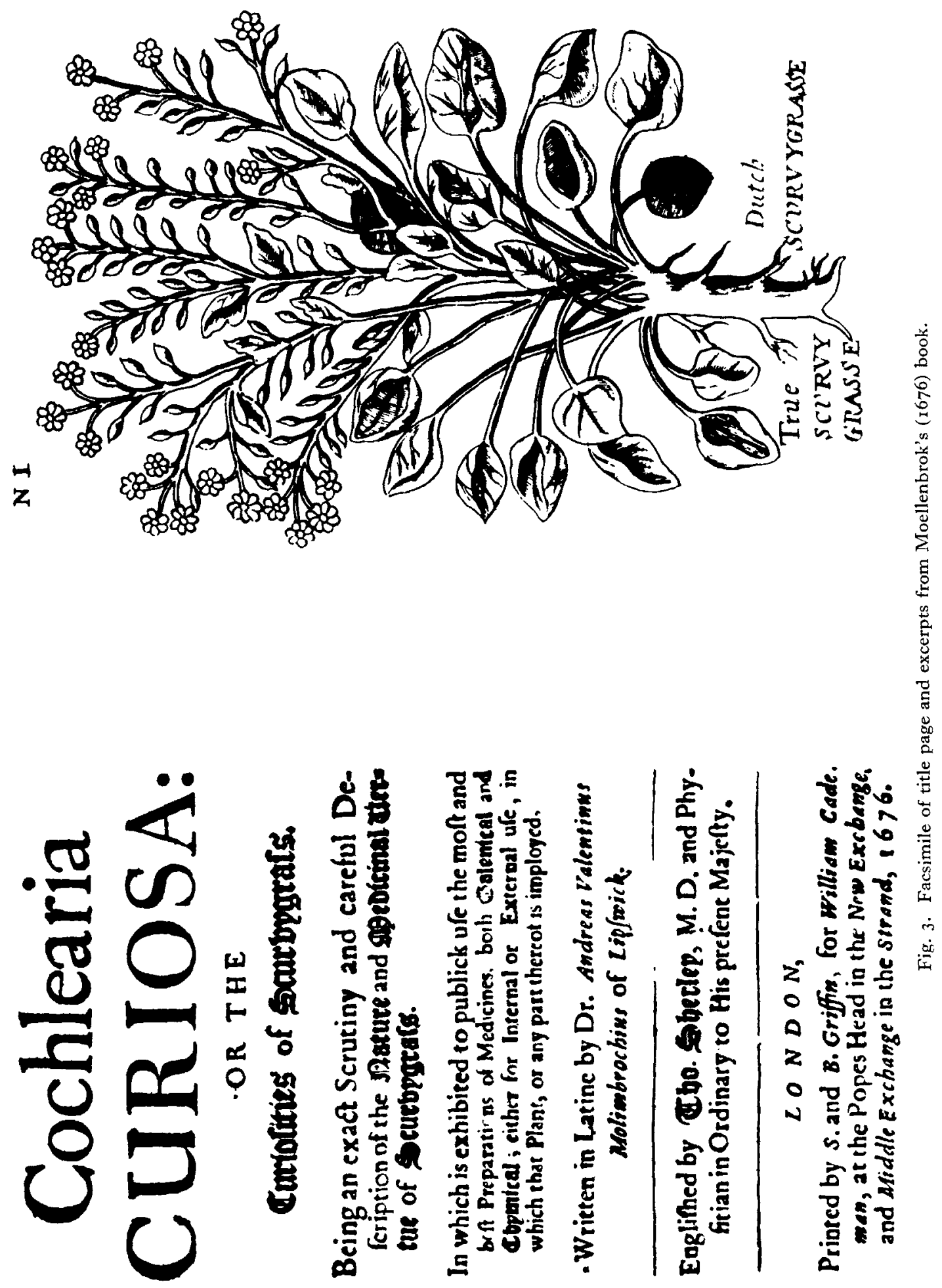




\section{CHAP. XIII.}

\section{of the Volatile sale of scurvygrafs.}

Glnce the Salt is the chief part, by $D$ means of which, scurvggrafs is fo prevalent in the Scurvy, according to the Philofophers Axiom : Per quod quid eft tale, illud eft magistale: That by obicts a thing is what it is, that thing is more juch. There is there. fore a neceffity, that we treat of this Salt. Arid becaufe of its volatility, but little of it can begotten, it is fufficient that we ufe its Spirit, in which this Salt is hid and contained. This Salt is made (after the fame manner that many others are, viz.) Let the thick leaves of scurvygrafs, and full of juice, be boiled a little while in water, and afterwards prefs out the juice, or which is better, if only the juice preffed out of the frelh gathered leaves be purified, and a little evaporated till it be fomewhat thickened, and fo fet by, till of its own accord the Salt fhoot in the juice. The chief efficacy of scur rygrafs (as hath been declared juft now, and alfo above in the fifth Chapter) is from the vola. tile Salt. For experience teacheth,

Fig. 3 cont. Facsimile of excerpts from Moellenbrok's (1676) book.

324 of his Parnassus Medicinus Illustratus (quoted by Moellenbrok, 1676), listing 'six several ways'*.

* In Sherley's translation the verse runs as follows:

Spoonwort doth warm, and also doth dry,

In the Scurvy 'tis a great Remedy,

It sends out all corrupt humors by sweat

With this your mouth gargel often, and wet.

This plant which deserves so much of your praise

The Apothecaries use six several wayes,

It's Spirit, Syrup, Water procures health,

So doth its Salt conserve, and th Herb itself. 
In cookery it was employed in the making of sauces, or as the Germans called them Tunken (vulgarly 'dips'), sometimes combined with the pulp of apples 'with cappers or with the pulp and juice of lemmons and wine or soure oranges'; or as a salad mixed with water cress. Such sauces, according to older authors, were particularly popular in Norway, just as rosehip conserves were used with winter dishes by my grandparents.

Conserves, decoctions and infusions of scurvy-grass leaves together with wine of scurvy-grass somehow bridged the gap between the household remedies and the apothecary's preparations, of which the 'spirit of Scurvygrass' was regarded the most efficacious. Several methods for its preparation are given, including the original technique of Johann Buttner, a German apothecary of Goerlitz, and that of the famous Danish naturalist, Simon Pauli. The alcoholic extract ('Spirit of Wheat or Rye, not the rectified Spirit of Wine') of the leaves was concentrated and the dosage was from ten to thirty drops in wine.

Electuaries, 'The medicine of a substance thicker than a syrup hardly liquid or fluid', were most often employed in filling the physician's prescription for a scurvygrass medicament. They were made from macerated freshly-gathered leaves, whereas the less popular and less effective elixirs or essences were made from the dried leaves.

'Certainly the volatile salt of scurvy-grass is lost in drying the leaves', says Moellenbrok (1676).

The final and most potent medicament from scurvy-grass, according to Moellenbrok, was his purified 'Volatile Salt of Scurvygrass'. He is explicit in his directions for making it, having, in directing the preparation of the previous compound, warned against prolonged exposure to air or heat. To introduce his idea of being able to concentrate the effective principle of scurvy-grass into a salt, when popularly salt was thought to cause scurvy, Moellenbrok cites the 'Philosopher's Axiom: "Per quod quid est tale, illud est magis tale"', which Moellenbrok's translator, Sherley, renders into Gertrude Stein-like English literally as follows: 'That by which a thing is what it is, that thing is more such'.

Moellenbrok clearly indicates that the production of his 'Salt of Scurvygrass', because of its small yield and its lability ('volatility') is not practicable for the apothecary and that therefore 'it is sufficient that we use its spirit, in which this salt is hid and contained'.

The chemical procedure is described as follows by Moellenbrok ( $1676, \mathrm{pp}$. I I $\left.2-\mathrm{II}_{3}\right)$ :

'Let the thick leaves of Scurvygrass, and full of juice, be boiled a little while in water, and afterwards press out the juice, or which is better, if only the juice pressed out of the fresh gathered leaves be purified, and a little evaporated till it be somewhat thickened, and so set by, till of its own accord the Salt shoot in the juice. The chief efficacy of Scurvygrass (as hath been declared just now, and also above in the fifth Chapter) is from the volatile Salt' (see Fig. 3).

I shall gladly leave it to the chemists to decide from the above whether or not Andrew Valentine Moellenbrok, the Leipzig pharmacist-chemist, in the middle 
of the seventeenth century actually isolated ascorbic acid and thus close the covers on the yellowed pages where

'Simply and gravely the facts are told

In the wonderful books of our fathers of old'.

\section{REFERENCES}

Anonymous (1682). The Natural History of Coffee, Thee, Chocolate, Etc., and also the Way of Making Mum. London: Christopher Wilkinson.

Boerhaave, H. (1728). Aphorismi de Cognoscendis et Curandis Morbis. Leyden: S. Leuchtmans and T. Haak.

Boerhaave, H. (1742). Aphorismi de Cognoscendis et Curandis Morbis. (Translation of Leyden Edition of 1728). London: Innys and Hitch.

Boerhaave, H. (1783). Traduction de Traité du Scorbut, Commenté par Van Swieten, G. Paris: Ches Mequigon.

Boyle, R. (1669). Occasional Reflections upon Several Subjects, 2nd ed. London: Henry Herrungman.

Boyle, R. (1696). Medicinal Experiments; or, a Collection of Choice and Safe Remedies Etc. 3rd ed. Vols. I \& 2. London: Samuel Smith and B. Walford for The Royal Society.

Bruner (Brunerus) B. (1 589). De Morbo Scorbuto (bound with Eugalenus). Amsterdam: J. F. Bernard.

Charleton, W. (1672). De Scorbuto Liber Singularis. Leyden; F. Lopez.

Clowes, W. (1596). Profitable and Necessarie Booke of Observations. London: by Edm. Bollifant for Thomas Dawson.

Colbatch, J. (1700). A Collection of Tracts Chirurgical and Medical. Viz: I. A Nerv Light of Chirurgery (4th ed. 1699). II. A New Light of Chirurgery vindicated (3rd Ed. I698). III. A Physico-medical Essay concerning Alkaly and Acid (including scurvy) (4th Ed, 1699). IV. Further Considerations concerning Alkaly and Acid. (4th Ed. 1699). V. A Treatise of the Gout, wherein etc. (3rd Ed.) Ptd by F. D. for D. Brown, and A. Bell. 1699. VI. The Doctrin of Acids in the Cure of Disease. The 2nd Ed. Inlarg'd 1699. VII. A Relation of a sudden and extraordinary Cure of a Person bitten by a Viper, by means of Acids etc. 2nd Ed. Inlarg'd 1699. All Corrected and Inlarg'd by fohn Colbatch, A Member of the College of Physicians. With an Alphabetical Table of the Whole. London: Dan Brown.

Comrie, J. (1932). History of Scottish Medicine. London: Bailtière, Tindall and Cox.

Echthius, J. (154I). De Scorbuto, vel Scorbutica Passione Epitome. Cologne.

Eugalenus, S. (1623). De Morbo Scorbuto Liber. Amsterdam: J. F. Bernard.

Fabricius, (Hildanus) W. (1629). De Conservanda Valetudine Etc. Frankfurt a.M.: M. Merianus.

Hartmann (1633). Praxis Chymiatrica. (Opus posthumum). Leipzig: G. Gross.

Kramer, J. (G.H.) (1737). De Scorbuto, Dissertatio Epistolica. Nuremberg: P. C. Monath.

Lind, J. (1753). A Treatise of the Scurvy, ist ed. Edinburgh: Sands, Murray and Cochran for A. Kincaid and A. Donaldson.

Lipenius, M. (1679). Biblioteca Realis Medica Etc. Frankfurt a.M.: J. Friederic.

Lister, M. (1694). Sex Exercitationes Medicinales. London: S. Smith and B. Walford.

Macbride, D. (1764). Experimental Essays (IV-On the Scurvy). London: A. Millar.

Macbride, D. (1767). An Historical Account of a New Method of Treating the Scurvy at Sea. London: Millar and Cadell.

Mercklin, G. A. (1686). Cynosura Medica. Nuremberg.

Moellenbrok (Molimbrochius) A. V. (I676). Cochlearia Curiosa. London: S. and B. Griffin for Wm. Cademan.

Plater, F. (1656). Praxeos Medicae. (Opus posthumum). Basle: E. Koenig.

Pliny, C. (70). Historiae Naturalis Liber (No. 25). London: G. Bohn (1855).

Ronsseus, B. ( $\mathrm{I}_{585}$ ). De Magnis Hippocratis lienibus Plinique stomacace ac sceletyrbe, seu vulgo dicto scorbuto commentariolus. Accessere ejusdem epistolae quinque ejusdem argumenti, foannis Echtii de scorbuto epitome, Foannis Wieri de scorbuto observatio. Foannis Langii epistolae duae de scorbuto. Wittenberg: C. Schleich.

Schmid, L. (1627). Quoted by Fabricius (Hildanus). Observ. et Curat. Chirurg. Frankfurt a.M.: M. Merianus.

Shipley, P. G. (1929). F. Amer. diet. Ass. 5, 1.

Sydenham, T. (1685). Observationes Medicae circa Morborum acutorum. London: Walter Kettilby.

Van Swieten ( 1783 ). Commentes (Boerhaave). Paris: Chez Mequignon.

Wier (Wierus) J. (1567). Medicarum Observationum Rararum Liber (I de Scorbuto). Basle: J. Oporinus.

Willis, T. (1684). Practice of Physicke (Translation) Part 10. Of the Scurvy. London: T. Dring, C. Harper, J. Leigh.

Woodall, J. (1639). The Chirurgeon's Mate, or Military and Domesticke Surgery. London: N. Bourne. 